\title{
On Diagnosing Business Communication Needs
}

\author{
Mounir Chibi, Jamal Akabli \\ Faculty of Letters and Human Sciences \\ Ibn Tofail University, Kenitra, Morocco \\ Email: mounir1720@gmail.com \\ jamal.akabli@hotmail.com
}

\begin{abstract}
The teaching/learning of Business English (BE) is so daunting a task that practitioners shy away from it, and learners avert it altogether unless they have to. Understanding students' needs is sure to change this perception and win students over. What better way to prompt students than by feeding teachers on what it takes for a business needs analysis to yield the much desired results. This article is two-fold in perspective being partitioned along two touchstones, oral and written communication, each of which is equally important.
\end{abstract}

Keywords-BE, business communication, GE, learners, needs analysis, practitioners.

\section{INTRODUCTION}

Understanding business needs is extremely vital to achieving the goals of $\mathrm{BE}$ practitioners. Hence, for a business course or syllabus to meet the learners' expectations, it should take their needs and wants into account. In other words, the fact that BE learners are goal-oriented and time-poor makes it mandatory for teachers and syllabus designers to devise time-saving and tailor-made courses to satiate the learners' motivation and meet with their satisfaction. Moreover, in a world where English is the lingua franca as well as the language of international business, a growing need for oral and written communication in English has surfaced. The focus of this article will be on the speaking and writing skills $\mathrm{BE}$ learners need in business environments.

\section{WHAT IS ESP?}

English for Specific Purposes (ESP) belongs to the field of English Language Teaching, yet its courses are goaldirected and aim at meeting the learners' needs. ESP is a learner- centered approach to teaching English where courses and syllabi center on learners' needs and motivations for learning the language (Hutchinson and Waters, 1987; Nunan, 1988). Dudley-Evans and St. John (1998, p. 4) provide a thorough definition that includes absolute and variable characteristics. The absolute characteristics imply that:

1. ESP is defined to meet specific needs of the Learners;
2. ESP makes use of underlying methodology and activities of the discipline it serves;

3. ESP centers on the language appropriate to these activities in terms of grammar, lexis, register, study skills, discourse and genre.

Dudley-Evans and St. John (1998, p.5), explain that variable characteristics are as follows:

1. ESP may be related to or designed for specific disciplines;

2. ESP may use, in specific teaching situations, a different methodology from that of general English (GE);

3. ESP is likely to be designed for adult learners, either at a tertiary level institution or in a professional work situation. It could, however, be for learners at secondary school level;

4. ESP is generally designed for intermediate or advanced students;

5. Most ESP courses assume some basic knowledge of the language systems.

\section{NEEDS ANALYSIS IN BUSINESS ENGLISH CLASSROOMS}

Dudley Evans and John (1998) maintain that ESP stipulates courses center on what learners need to do with English in a professional context. Thus, needs analysis is the crucial part of the teaching and syllabus design processes. BE as a branch of ESP differs widely from GE. Learners of each discipline have particular expectations that cannot be fully met by either BE or GE. BE learners

BE learners have specific needs; they come into class knowing what to expect (Frendo, 2005). They hope for the learning experience to be such as would enable them to operate in any given business context. In BE classes, teachers have to be wary of what to teach to meet learners' 'business needs'. This term is worth probing as it constitutes the threshold to a successful teaching/learning experience. The needs of a learner represent the gap between what the learner wants to make out of the learning experience and his or her current state of knowledge, skills and enthusiasm (Donna, 2000; Ellis and Johnson, 1994). In a similar vein, Hutchinson and Waters (1987) have it that learners have different needs 
and interests, which would have an important influence on their motivation to learn and, therefore, on the effectiveness of their learning. This lent support to the development of courses in which 'relevance' to the learners' needs and interests was paramount. (p. 8)

Frendo (2005, p. 17) argues that "different types of communication inevitably give rise to different types of communication needs" that business classes must seek to satiate. In this perspective, communication needs are the backbone of BE classes. Such needs require being thoroughly analysed to ensure effective teaching and learning outcomes (Hutchinson and Waters, 1987).

\section{BUSINESS COMMUNICATION NEEDS}

Oral and written communication needs have tremendous importance in the teaching of BE (Frendo, 2005). Hence, prioritising the communicative use of English language knowledge through communication skills will enable BE learners to develop good communicative competence and function successfully in their professional life (Brieger, 1997). To put it differently, learners will have necessary input on how to use different types of discourse in different target situations (Frendo, 2005).

\subsection{Oral Communication Skills}

Learning effective oral communication skills is primordial to succeeding both academically and professionally (Brieger, 1997). In formal situations, a misconducted talk, interview, or a presentation could damage the goodwill of the speaker as well as put at risk the company's image. By whetting one's communication skills, a learner will acquire the skills required to confidently operate in a variety of personal, professional, and academic situations.

What learners should be aware of is that oral communication is not only confined to the language used for communication, but it also includes a broad continuum comprising eye contact, body language, audience awareness, active and reflexive listening, effectiveness, clarity and conciseness, etc (Rahman, 2010). In short, to empower students to communicate effectively and efficiently, teachers should impart a range of communication skills. In this perspective, BE learners need to master the language and oral skills such as socialising, small talk, telephoning, giving presentations, holding meetings, and conducting negotiations (Brieger ,1997; Donna, 2000; Frendo, 2005).

\subsubsection{Socialising}

Socialising is a relevant skill through which a great deal of business-related interaction takes place in various business settings (Dudley Evans and ST John,1998). In the world of business, the way people converse can either polish or tarnish their image, i.e. socialising appears crucial in creating that much needed rapport with one's business associates (Frendo, 2005).

To operate effectively while socialising, learners must be equipped with adequate knowledge of the language of meetings, greetings, and dining out and so on and so forth. What is even more important is that a speaker should learn the strategies needed to keep conversations flowing smoothly. They also need to know when and how to tell purposeful anecdotes or stories. Failing to give heed to these minute details can have serious ramifications.

In general, every means to promoting a fair exchange of information or boosting positive social interaction can serve in these situations. Having said this, one should be warned that a good command of language is hardly sufficient to warrant a successful conversation; understanding cultural differences is a contributory factor to effective communication (Donna, 2000).

\subsubsection{Small talk}

Preparing a BE learner to achieve spoken communicative competence should not only be restricted to speaking about work, but it should also extend to cover non-work issues. Small talk may take place during a coffee break, just before a meeting starts, or while socialising, for example (Frendo, 2005). Differently put, small talk means talking about minor things that are not purely businessrelated, but that do make a difference to the outcome of business talk to come. Small talk fills the gap during silence or helps move from one topic to another.

However, successful small talk is contingent upon the interaction of the addressee with the addresser. Sometimes, it accentuates a previously established relationship between people. Conducting such talks requires acquiring the skills to prepare learners to engage politely and fruitfully while addressing interlocutors or being addressed inadvertently. This includes routine topics such as the weather, travel to the place of meeting, topics about the visitors' own country or town, etc. (Ellis and Johnson, 1994).

\subsubsection{Telephoning skills}

Telephoning, as a channel of communication, can be described as a performance area that includes a "wide range of situations and types of interaction. This is because the language used on the telephone is highly conventional and formalized" (Ellis and Johnson, 1994, p. 98). The telephone register is so specific that some of its expressions are limited to use in telephone conversations. On another plane, making phone calls is a nightmarish task business learners are doomed to face while at the office, especially if calls are made without previous 
preparation and often received unexpectedly (Donna, 2000).

What fuels the fire is the invisibility of the speaker, that is, while talking to the interlocutor at the other end, the sole means of communication is the speakers' voice; no facial expressions or body language can serve in such cases. Sometimes, the sound may not be clear and the speaker's pace is too quick to be fully grasped (Dudley Evans and ST John, 1998). Therefore, Frendo (2005) contends that being a good communicator entails providing learners with ample learning situations and exposing them to the frequent telephone expressions to deal effectively with customers, keep them satisfied and convinced, and be accurate while transmitting information. Briefly put, students require a good mastery of "standard lexical phrases" and "survival strategies" (Frendo, 2005, p. 66) to operate effectively in professional settings and situations.

\subsubsection{Presentational skills}

Presentation skills form an integral part of business oral communication learners of BE undoubtedly need to operate effectively in the world of business. Presentations "can be a feature of EOP or EAP work" (Dudley Evans and ST John, 1998, p.112); nevertheless, delivering presentations is not as easy as some people might think. For a host of learners or professionals, it is nothing but frustrating and embarrassing, to say the least. Thus, being a successful speaker requires at one and the same time being accurate and fluent to convey and purvey messages clearly.

Using signposting and rhetorical language, such as tripling, emphasizing, and rhetorical questions are typical components of the language BE learners should be able to use during the delivery of presentations (Brieger ,1997). In other words, giving presentations necessitates preparing students for and providing them with the necessary input to overcome so challenging a task as this one. Being successful at giving presentations is incumbent upon confidence and mastery of the topic, language, and being wary of the cultural specificity of the addressee. These criteria play a vital role in building the goodwill of the company or that of the manager before their audience. On another level not far removed from this one, business presentations require being orally skilful, using visual aids tactfully, and exploiting techniques of delivery to the best of one's ability. Content is also to be specific, coherent, and concise; verbiage kills presentations and renders them tedious, if not repulsive (Frendo, 2005).

\subsubsection{Conducting meetings}

Having meetings is oftentimes a conventional activity in business environments. Meetings can be either formal or informal depending on various factors. Meetings vary according to people's rank, cultural background and circumstances. A meeting with a chairperson or chief executive officer, for instance, is formal. Informal meetings can include having coffee together while discussing some minor issues. Meetings can be held to discuss major business issues or to hand down corporate instructions (Frendo, 2005). Sometimes, holding a meeting depends on the significance of the issue and the participants involved.

To function successfully in meetings, learners need to be equipped with the necessary skills. As a case in point, having knowledge about formal and informal lexical items and their use will help business learners to act accordingly. The focus should be placed on the language that facilitates passing on information, persuading, justifying, defending one's position, arguing, and summarising. Gambits" phrases such as "hang on a minute" or "can I make a point" serve to facilitate entry in meetings (Dudley Evans and ST John, 1998, p.110)

\subsubsection{Negotiation skills}

Learners are expected to excel at negotiating, another skill needed in the field of business. Negotiations are simply another form of meeting where business people gather to negotiate transactions and deals. Much of the art of negotiation is built around the concept of give and take (Brieger, 1997). Succinctly put, it centers on the ability of the negotiator to convince people or companies to accept a deal, sign a contract, or to invest in potential lucrative areas.

For BE learners to operate effectively while negotiating, they need to be aware of the different stages and types of negotiation. Knowledge of the types of negotiations and the stages they go through enables learners to adopt the appropriate language in the suitable context (Donna, 2000). The stages for a successful negotiation include: preparation, relationship building, information gathering, information using, and bidding, closing the deal, and implementing the agreement (Frendo, 2005).

Business learners need to differentiate between two main types of negotiation, disruptive, competitive, win-lose negotiating and integrative/win-win negotiating. Disruptive negotiating refers to the situations where/when a conflict of interest between the negotiating parties comes to the fore. Each party has a goal to achieve and interests to defend; the focal point is to gain advantages over other parties at the end of the negotiations (Frendo, 2005). In contrast, integrative/win-win negotiating focuses on what the parties involved have in common. 
Such a type of negotiation has as its ultimate goal finding alternative solutions to seek compromise over issues or deals that guarantee both parties' gains and benefits. In other words, discussions taking place during negotiations try to establish an arena for shared interest, seeking to satisfy both parties' needs (Frendo, 2005).

It is worth noting that questioning and active listening constitute the core of most of the aforementioned oral communicative skills. Decoding and understanding the addresser's message during telephone conversations, presentations, meetings, and negotiations play a vital role in business interaction. While interacting, speakers use a range of questions such as closed-response questions, limited-response questions, open-questions, probing questions, and building questions (Dudley Evans and ST John, 1998).

\subsection{Wrtitten Communication}

Written communication is much easier than spoken communication. In other words, writing is not a spontaneous act of communication where a face to face interaction obliges speakers to respond quickly and instantly. While writing, people have time to read and analyse the sender's message and prepare a suitable reply (Frendo, 2005). Nonetheless, written communication poses a lot of challenges. Writing is not spontaneous, for it requires a specific toolkit. To explain, writing requires skills in spelling, punctuation, grammar, linking paragraphs, and a careful choice of words. Required also in writing is "the skills of planning, drafting, and revising so that the end product is appropriate both to the purpose of the writing and the intended readership" (Dudley Evans and ST John, 1998, p.115). Business writing skills in business environments include writing a number of genres. BE learners need to exchange and write letters and emails, write and read contracts, reports, CVs, motivation letters, agendas and minutes, etc. (Frendo, 2005, Brieger; 2007).

\subsubsection{Letters, emails and faxes}

Writing letters, emails and faxes form the backbone of business correspondence. What distinguishes correspondence in general and business in particular is the fact that correspondence is governed by means of giveand-take to ensure dissemination and receipt of information. Students need to be able to write "different types of letters and commercial documents dealing with issues such as enquiries, offers, orders, acknowledgements, delivery, payment, delays, complaints, credit, job applications, insurance, making arrangements" (Frendo 2005, p. 87). To achieve this level, students should be taught useful phrases and expressions frequently employed in business correspondence.
Business correspondence has its own layout, rules, conventions, tone, and style that students should study thoroughly and respect to function successfully as professional communicators (Brieger, 2007). By the same token, students need a good mastery of specialist terms such as Incoterms (International commercial terms). Acronyms like: EXW (ex-works) or FOB (free on board) are standard trade definitions published by the International Chamber of Commerce that are in wide circulation in commercial correspondence (Frendo, 2005).

\subsubsection{Contracts}

Contracts are another common writing genre in the world of business. Contracts document and legalise the agreement between two parties or more to respect the terms they have agreed upon. Business students need to read, interpret, and "engage in contract-related written correspondence and amendments" (Frendo, 2005, p.90). BE learners should be able to deal with the following contract elements:

$>$ Introduction with definitions and names of various parties.

$>$ A time frame for the agreement.

$>$ Terms of payment and delivery.

$>$ Responsibilities and undertakings of each party.

$>$ Insurance details in case of problems.

$>$ Dispute resolution or arbitration arrangements.

$>$ Appendices and other accompanying documents.

\subsubsection{Reports}

Reports also play a pivotal role in business settings. Reports refer to "documents which offer the reader the results of an enquiry of some sort (such as research, technical inspection, visit, and feasibility studies) or an account of some event(s)" (Frendo, 2005, p.91). Reports have their own formats and content that learners should respect while writing. Students also need to be capable of writing numerous types of reports and know about their conventions (Donna, 2000). For instance, learners should know that a report includes an introduction, a body, and a conclusion. In general, Thompson (2005) contends that BE learners should be able to:

- Determine the scope (purpose) of the report,

- consider the target audience (readers),

- gather information and organize the supporting information (research),

- analyze, and weigh the supporting information,

- determine the solution, findings, and the report format. 


\subsubsection{CVs and motivation letters}

$\mathrm{CVs}$ and motivation letters writing remain a life-breather skill BE learners are to master. The value of both forms, $\mathrm{CV}$ s and motivation letters, stems from the role they play together in qualifying their candidates for prospective posts or in securing a job. Knowing about the do's and the don'ts of writing both CVs and motivation letters is compulsory for BE learners to sound more professionallike while applying for a job. Like the previously mentioned forms of business writing, format, punctuation and style form part of the quality of $\mathrm{CVs}$ and cover letters. However, such constituents are not universal, for they culture-based. For this reason, students should have enough lexical input. For instance, students who seek a job in the USA need to use verbs with a positive connotation to describe their achievements. This includes verbs like: created - conducted - coordinated - improved - designed - assisted - provided - addressed - established - solved (Frendo 2005).

\subsubsection{Agenda and minutes}

Agenda and minutes writing are necessary genres in business writing. In business, an agenda refers to the ordered sequence of the main points and issues to be raised at a formal meeting (Brieger, 2007; Frendo, 2005). Students of BE should have insights into how and what to write in an agenda. Aagendas do not have a fixed shape. They can vary in form and size, according to the job environment.

Minutes, unlike agendas, are records of what takes place in meetings. They function as 'prima facie evidence', evidence that establishes a fact but is not a conclusive piece of evidence of its existence. In business, three types of minutes are the most frequently adopted. These kinds may differ in both style and detail. For Frendo (2005, p. 93), these types are as follows:

$\checkmark$ Minutes written to record internal meetings; these are attended by company personnel, and are only to be used internally. These can be quite informal, and may take the format of action notes (simply recording names of who is doing what by when).

$\checkmark$ Minutes written to record meetings with outside agencies (customers or partners), but for internal use only. These will often include subjective comments.

$\checkmark \quad$ Minutes written to record meetings with outside agencies (customers or partners), but for shared use or publication. These are often the most formal, and may form the basis for negotiations or contracts.

\section{CONCLUSION}

ESP posits that various learners in any given context face specific problems which need to be minutely diagnosed and sorted out through appropriate and adequate teaching. ESP specialists have a variety of roles to take on. They are called upon to assess needs and later to design corresponding curricula and implement the content in such a way as would respond to the identified needs. Assessment is thus seen as the foundational principle, the touchstone, upon which decisions regarding oral and written skills are premised and reached. Learning BE is then much more complex than it seems. This being said, a meticulous teacher can make the task inviting by taking account of all the above for an optimal outcome to enable learners to operate to the best of their ability in the target situation(s) by deploying and employing the oral/written skills they have internalised. What appears to be daunting can be surmounted with informed decisions about what to teach and how to teach it. While it is easy to lose one's audience given the nature of the subject being taught, practitioners can capitalize on students' motivation to achieve the best possible result.

\section{REFERENCES}

[1] Brieger, N. (1997). Teaching Business English Handbook. York, England: York Associates.

[2] Donna. Sylvie, (2000). Teach Business English. Cambridge, United Kingdom: Cambridge University Press.

[3] Dudley-Evans, T., \& St John, M. J. (1998). Developments in English for specific purposes: Cambridge University Press.

[4] Ellis, M., \& Johnson, C. (1994). Teaching business English. Oxford: Oxford University Press.

[5] Frendo, E. 2005. How to teach business English. Harlow: Pearson Education Limited.

[6] Nunan, D. (1988). Syllabus design. Oxford, England: Oxford University Press.

[7] Rahman, M. M. (2010). Teaching oral communication skills: A task-based approach. ESP World, 9 (27), Retrieved Mai 19, 2012, from http://www.esp- world.info/ articles_27/paper.pdf

[8] Thompson, A (2005). Entrepreneurship and Business Innovation. Vineyard Publishing, 2005 